\title{
Induction of Apoptosis by an Extract of Persian Gulf Marine Mollusc, Turbo Coronatus through the Production of Reactive Oxygen Species in Mouse Melanoma Cells
}

\author{
Fatemeh Zangeneh ${ }^{1}$, Amir Vazirizadeh ${ }^{2}$, Mohammad Reza Mirshamsi ${ }^{1}$, \\ Amir Fakhri ${ }^{1}$, Mehrdad Faizi ${ }^{1 *}$, Jalal Pourahmad ${ }^{1 *}$
}

\begin{abstract}
Objective: A variety of approaches such as surgery, chemotherapy, radiotherapy, hormonal therapy and immunotherapy are used to treat melanomas, but unfortunately in most case, the response is very weak and often side effects are serious. This study concerns selective toxicity of an extract of Turbo coronatus on cells and mitochondria from a syngeneic mouse model of melanoma. Methods: Cells and mitochondria isolated from extra tumoral and melanoma tissues were exposed toa T. coronatus crude extract and fractions obtained by gel-filtration chromatography and assayed for mitochondrial and cellular parameters. Result: Crude extract (375, 750 and 1,500 $\mu \mathrm{g} / \mathrm{ml})$ and fraction 1; F1; (275, 550 and $1100 \mu \mathrm{g} / \mathrm{ml})$ of $\mathrm{T}$. coronatus extract induced a significant $(\mathrm{p}<0.05)$ increase of the reactive oxygen species (ROS) level, swelling of mitochondria, collapse of mitochondrial membrane potential (MMP), release of cytochrome $\mathrm{c}$ and caspase-3 activation only in the mitochondria and cells obtained from melanoma but not extra tumoral tissues. In addition, the F1 fraction decreased the percentage of viable cells and induced apoptosis in melanoma cells. Conclusion: For the first time we could demonstrate that the F1 fraction of a T. coronatus extract, selectively induces ROS mediated cytotoxicity by directly targeting mitochondria in melanoma tissues and it may be a suitable candidate for novel drug treatment of malignant melanomas.
\end{abstract}

Keywords: Melanoma- turbo coronatus- mitochondria- apoptosis- gel filtration- Persian Gulf

Asian Pac J Cancer Prev, 19 (12), 3479-3488

\section{Introduction}

Cancer can be defined as an uncontrollable proliferation of an unusual cell group with disregard to cell division of normal rules. One of the most dangerous types of skin cancer, originating from melanocytic cells, is melanoma (Dana et al., 2015). Epidemiological studies have shown that the incidence of melanoma is increasing at a faster rate than any other cancers worldwide (Hoel et al., 2016). It is predicted 91,270 new cases of melanoma will be diagnosed and 9,320 deaths occurred from melanoma in 2018 only in the U.S.A (Siegel et al., 2018). Moreover, although melanoma can be treatable at the early stage of diagnosis, invasive melanoma has a poor prognosis due to various resistance mechanisms to treatment options such as chemotherapy (Looi et al., 2013). Most chemotherapy drugs eventually affect through induction of apoptosis (Grossman and Altieri, 2001). Studies have shown that the inability to induce apoptosis in melanoma cells due to impairment of the pathway and the level of pro/anti apoptotic factors such as defective in cytochrome c release and high levels of the apoptosis inhibitor FLIP (Grossman and Altieri, 2001; Tian et al., 2012). Therefore all the efforts should be focused on new cytotoxic agents with the ability to induce apoptosis in melanoma cells. Marine environment covers more than $70 \%$ of the Earth's surface (Ruiz-Torres et al., 2017). It is a unique resource of potent bioactive compounds with special chemical and structural properties that are not found in terrestrial natural products. Recently, the enormous number of novel potential compounds with pharmacological features isolated from various marine species such as microorganisms as well as invertebrates (sponges, bryozoans, tunicates, molluscs, etc.) (Chen et al., 2015; Malve, 2016; Ruiz-Torres et al., 2017). Many of these bioactive compounds are currently in clinical phases as antineoplastic candidates (Malve, 2016; Ruiz-Torres et al., 2017).

Turbo coronatus is a kind of turban snail, belongs to the turbinidae family, which is widely distributed in the Persian Gulf rocky shores. Recent research indicates 
that IV injection of the crude extract $T$. coronatus to rats produced rhabdomyolysis and hepatocytes injury (Vazirizadeh et al., 2017). Turbostatins 1-4 (type of cerebrosideare) novel antineoplastic agents are isolated from T. stenogyrus. All four agents exhibited significant cancer cell growth inhibition against the murine P388 lymphocytic leukemia and a panel of human cancer cell lines (Pettit et al., 2005). Another study on the Genus marmorata led to the identification and isolation of turbotoxin A and B, Diiodotyramine derivative which revealed acute toxicity against ddY mice and turbotoxin A inhibits acetylcholinesterase (Kigoshi et al., 2000). The aim of the present study is was to investigate the selective cytotoxicity of $T$. coronatus crude extract and its fractions against the cancerous cells and mitochondria isolated from a mouse model of melanoma and discovering the possible upstream events leading to ROS mediated apoptosis and compared our findings with those of from autologous extra cancerous skin cells and mitochondria isolated from the same mouse model of melanoma.

\section{Materials and Methods}

\section{Sample Collection and crude extract Preparation}

A total of $2.2 \mathrm{~kg}$ of the mollusk $T$. coronatus was collected from tidal and rocky shores of the Persian Gulf beaches from Bandar Bushehr $\left(28.9234^{\circ} \mathrm{N}\right.$ latitude and $50.8203^{\circ} \mathrm{E}$ longitude). The samples were immediately transported to the laboratory and the viscera were removed by breaking the shells. The whole body muscles of the sample (450 g) were ground to a powder under liquid nitrogen and homogenized with $30 \mathrm{~mL}$ of $0.15 \mathrm{M}$ saline solution at $4^{\circ} \mathrm{C}$. The homogenate in obtained was centrifuged $(12,000 \times \mathrm{g} \mathrm{30})$. The supernatant was immediately freeze-dried (Christ, UK) and kept on $-20^{\circ} \mathrm{C}$ until further use (Vazirizadeh et al., 2017). The protein concentration of the T. coronatus extract was determined by the Bradford method (Bradford, 1976).

\section{Gel Filtration Chromatography (GFC)}

Sephadex G-50 (Pharmacia, USA) gels were poured into a $2.5 \times 150 \mathrm{~cm}$ diameter. The elution was completed with $0.2 \mathrm{M}$ ammonium acetate $\left(\mathrm{pH} 7.1\right.$ at $\left.4{ }^{\circ} \mathrm{C}\right)$ and flow rate adjusted to $1 \mathrm{ml} / \mathrm{min}$. About $600 \mathrm{mg}$ of crude extract of T.coronatus was dissolved in $10 \mathrm{ml}$ of $0.2 \mathrm{M}$ ammonium acetate. After centrifugation at $5,000 \times \mathrm{g}$ for $10 \mathrm{~min}$ at $4{ }^{\circ} \mathrm{C}$, the supernatant was loaded on the column of Sephadex G-50. Fractions were collected and protein absorbance was measured at $280 \mathrm{~nm}$ by UV spectrophotometer. Eventually the lyophilized fractions and were stored until use at $-20^{\circ} \mathrm{C}$ (Samel et al., 2008).

\section{Animals}

Female C57BL/6 mice (8-10 weeks old, weighting 16-18 g) were purchased from the Pasture Institute of Iran. The animals were housed in a regulated condition $\left(22 \pm 2{ }^{\circ} \mathrm{C}, 50 \pm 5 \%\right.$ humidity) with a $12 \mathrm{~h}$ light/dark cycle (8 AM-8 PM). All the experiments were conducted according to instructions of ethical standard and Institutional Animal Care and Use Committee (IACUC) of Shahid Beheshti University of Medical Sciences,
Tehran, Iran.

\section{Induction of syngeneic melanoma model}

Using published protocols mice received subcutaneous injections cells $\left(1 \times 10^{5}\right.$ in $0.2 \mathrm{M}$ phosphate buffered saline) B16-F10 in the right flank. When the syngeneic implantation was established (usually 14 to 21 days) based on the visibility of tumor the mice were sacrificed. After removing the tumors, they are cut into $2 \mathrm{~mm}$ pieces and were implanted in the right flank C57BL/6 mouse by using a 15-gauge trocar $12 \mathrm{~mm}$ long (Overwijk and Restifo, 2001).

\section{Mitochondrial Isolation}

After induction of melanoma, on day 7-10 after subcutaneous implantation of tumor the animals were anesthetized with ketamine $(80 \mathrm{mg} / \mathrm{kg}$, i.p.) and xylazine $(5 \mathrm{mg} / \mathrm{kg}$, i.p.). For mitochondria isolation from melanoma and extra tumoral tissues, samples were washed with cold isolation buffer (sucrose $0.25 \mathrm{M}$, TrisHCl $5 \mathrm{mM}, \mathrm{pH}$ 7.4, and EDTA $1 \mathrm{mM}$ ), then chopped and homogenized with glass hand-held homogenizer. The homogenate was centrifuged at $2,000 \times \mathrm{g}$ for 10 min at $4{ }^{\circ} \mathrm{C}$ for discard the pellet containing the nuclei, unbroken cells, tissue debris. The supernatant obtained from the first step was centrifuged at $10,000 \times \mathrm{g}$ for 10 min to obtain pellet containing purified mitochondria and then suspended in cold Tris buffer (Tris- $\mathrm{HCl}, 0.25 \mathrm{M}$ of sucrose, $20 \mathrm{mM}$ of $\mathrm{KCl}, 2.0 \mathrm{mM}$ of $\mathrm{MgCl} 2$, and $1.0 \mathrm{mM}$ of $\mathrm{Na}_{2} \mathrm{HPO}_{4} ;(\mathrm{pH}=7.4)$ at $\left.4{ }^{\circ} \mathrm{C}\right)$ (Lampl et al., 2015). Protein concentrations were determined using the Bradford assay through the coomassie blue protein-binding method using BSA as the standard.

\section{Succinate Dehydrogenase (SDH) activity assay}

The activity of SDH (complex II) was measured by the reduction of MTT (3-[4, 5-dimethylthiazol-2-yl]-2, 5-diphenyltetrazolium bromide) to formazan at $570 \mathrm{~nm}$. Briefly, to carry out this assay, $100 \mu \mathrm{l}$ of mitochondrial suspensions (1 $\mathrm{mg}$ protein $/ \mathrm{mL}$ ) was incubated with different concentrations of crude extract and its fractions $(0,250,500,1,000,1,500$ and $2,000 \mu \mathrm{g} / \mathrm{ml})$ at $37{ }^{\circ} \mathrm{C}$ for $1 \mathrm{~h}$; then, $25 \mu \mathrm{l} 0.4 \%$ of MTT was added to the medium and incubated at $37^{\circ} \mathrm{C}$ for $30 \mathrm{~min}$. Finally the formed crystals of formazan, were dissolved in $100 \mathrm{ml}$ DMSO and then the absorbance at $570 \mathrm{~nm}$ was measured with an ELISA reader (Tecan, Rainbow Thermo, Austria) (Salimi et al., 2015). In the present study for determination of the other mitochondrial toxicity parameters, we applied concentrations of $1 / 2 \mathrm{IC}_{50}, \mathrm{IC}_{50}$ and $2 \mathrm{IC}_{50}$ for crude extract and selected fractions (Fakhri et al., 2017).

\section{ROS (reactive oxygen species) formation assay}

Briefly, isolated mitochondria from cancerous and extra cancerous tissues were suspended in dichlorofluoresceindiacetate (DCFH-DA) fluorescent probe (final concentration of $10 \mu \mathrm{M}$ ) as a reagent and respiration assay buffer $(0.32 \mathrm{mM}$ of sucrose, $10 \mathrm{mM}$ of Tris, $20 \mathrm{mM}$ of Mops, $50 \mu \mathrm{M}$ of EGTA, $0.5 \mathrm{mM}$ of $\mathrm{MgCl}_{2}, 0.1 \mathrm{mM}$ of $\mathrm{KH}_{2} \mathrm{PO}_{4}$, and $5 \mathrm{mM}$ of sodium succinate) and incubate with variousconcentrations of 
crude extract and its $\mathrm{F} 1$ fraction at $37{ }^{\circ} \mathrm{C}$ for $10 \mathrm{~min}$. Then, the DCF fluorescence intensity was assayed using Shimadzu RF-5,000U fluorescence spectrophotometer at an excitation wavelength of $488 \mathrm{~nm}$ and emission wavelength of $527 \mathrm{~nm}$ (Seydi et al., 2016a).

\section{Mitochondrial swelling assay}

Mitochondrial swelling was evaluated from decrease in absorbance measured by spectrophotometer at $540 \mathrm{~nm}$ which indicates an increase in mitochondrial swelling. The obtained mitochondria from cancerous and extra cancerous tissues were suspended in swelling buffer (70 $\mathrm{mM}$ of sucrose, $230 \mathrm{mM}$ of mannitol, $3 \mathrm{mM}$ of HEPES, $2 \mathrm{mM}$ of Tris-phosphate, $5 \mathrm{mM}$ of succinate, and 1 $\mu \mathrm{M}$ of rotenone) and incubated at $30^{\circ} \mathrm{C}$ with different concentrations of crude extract and its $\mathrm{F} 1$ fraction at $30^{\circ} \mathrm{C}$ for one hour. The absorbance was measured at 5, 15, 30, 45 and 60 min time intervals using an ELISA reader (Tecan, Rainbow Thermo, Austria) (Talari et al., 2014).

\section{Mitochondria membrane potential (MMP) assay}

In this study, the effect of crude extract and fraction 1; F1 on the mitochondria membrane potential (MMP) was assayed using re-distribution technique of Rhodamine 123 (Rh 123). In the first step, the isolated mitochondria from cancerous and extra cancerous tissues were placed in 1 $\mathrm{ml}$ of MMP assay buffer $(220 \mathrm{mM}$ of sucrose, $68 \mathrm{mM}$ of D-mannitol, $10 \mathrm{mM}$ of $\mathrm{KCl}, 5 \mathrm{mM}$ of $\mathrm{KH}_{2} \mathrm{PO}_{4}, 2 \mathrm{mM}$ of $\mathrm{MgCl}_{2}, 50 \mu \mathrm{M}$ of EGTA, $5 \mathrm{mM}$ of sodium succinate, 10 $\mathrm{mM}$ of HEPES, and $2 \mu \mathrm{M}$ of rotenone) for 1 hour. Then various concentrations of crude extract, its F1 farction and $\mathrm{Rh} 123(10 \mu \mathrm{M})$ were added to it. The fluorescence activity of the cytosolic Rh 123 was determined at the excitation wavelength of $490 \mathrm{~nm}$ and emission wavelength of $535 \mathrm{~nm}$, by using a fluorescence spectrophotometer (Schimadzou RF-5,000U) (Eskandari et al., 2012).

\section{Cytochrome c release}

The concentration of cytochrome $\mathrm{c}$ released from the mitochondria into the cytosolic fraction in response to various concentrations of crude extract and its F1 farction of $T$. coronatus, was measured at $450 \mathrm{~nm}$ according to the instructions provided by the manufacturer of the Quantikine Human Cytochrome c Immunoassay kit (R and D Systems, Inc., Minneapolis, USA). All analysis stages were carried out using an ELISA reader (Infinite M 200, TECAN) (Naserzadeh et al., 2017).

\section{Determination of Cytotoxicity by MTT assay}

Healthy and cancerous cells $\left(1 \times 10^{6}\right.$ cells $\left./ \mathrm{ml}\right)$ isolated from extra tumoral and melanoma tissues, respectively, were plated in 96-well plates and treated with $0-2,000$ $\mu \mathrm{g} / \mathrm{ml}$ concentrations of) The $\mathrm{F} 1$ fraction of $T$. coronatus extract for 12 hours (Cells were maintained in RPMI 1640, supplemented with $10 \%$ FBS and antibiotics $(50 \mathrm{U} / \mathrm{ml}$ of penicillin and $50 \mu \mathrm{g} / \mathrm{ml}$ streptomycin). After treatment, 25 $\mathrm{mL}$ of MTT ( $5 \mathrm{mg} / \mathrm{ml}$ in RPMI 1640) reagent was added to each well. After $4 \mathrm{~h}$, the reaction was stopped by the addition of $100 \mu \mathrm{l}$ of DMSO. The optical density was read at $580 \mathrm{~nm}$ wavelength in an ELISA plate reader.

\section{Caspase-3 activity assay}

The effect of crude extract and F1 fraction on the activation of caspase- 3 on the mitochondria from melanoma and extra tumoral cells were evaluated according to the instructions of the Sigma's caspase-3 colorimetric assay kit (CASP-3-C; Sigma-Aldrich, Saint Louis, USA). Eventually, the concentration of the p-nitroaniline (pNA) released from the substrate at 405 $\mathrm{nm}$ was calculated for assessment caspase-3 activity or from a standard curve prepared with defined p-nitroaniline solutions (Seydi et al., 2016b).

\section{Apoptosis versus necrosis assay}

Cells obtained from the extra tumoral and melanoma tissues $\left(1 \times 10^{6}\right.$ cells $\left./ \mathrm{ml}\right)$ were exposed to $500 \mathrm{mg} / \mathrm{ml}$ (IC50) concentration of F1 fraction in duration 12 hours. Briefly double staining with Annexin V-fluorescein isothiocyanate (FITC) / propidium iodide (PI) was performed using a commercial kit (Immunotech; Beckman Coulter) and the fluorescence signals of Annexin V and PI were measured by flow cytometry (Cyflow Space-Partec) (Qiu et al., 2012).

\section{Statistical analysis}

Assays were performed using the GraphPad Prism software (version 6). Data were showed as mean \pm SD and assays were performed in triplicate. Comparisons were made using the one-way (followed by the post-hoc Tukey test) and two-way (Bonferroni post-hoc test) ANOVA tests. $\mathrm{P}<0.05$ was considered as level of significance.

\section{Results}

\section{Gel filtration chromatography (GFC)}

To investigate the cytotoxic effect of fractions, we first fractionated $T$. coronatus crude extract using gel filtration chromatography. As shown in Figure 1, the Chromatogram of $T$. coronatus crude extract on Sephadex G-50 revealed four obvious peak (F1-F4) with absorbance at $280 \mathrm{~nm}$.

\section{Effect of crude extract and fractions of T. coronatus on SDH activity}

The effect of crude extract $T$. coronatus and its fractions (F1-F4) $(0,250,500,1000,1500$ and $2000 \mu \mathrm{g} / \mathrm{ml})$ on SDH after 60 minutes was determined by MTT assay. As shown in Figure 2 (B, D, F, H, J) in the mitochondria obtained from melanoma tissue, crude extract and F1-F4 fractions of $T$. coronatus induced significant $(\mathrm{P}<0.05)$ reduction in the SDH activity. However, only F1 fraction of extract caused a significant $(\mathrm{P}<0.05)$ concentration-dependent reduction of mitochondria succinate dehydrogenase activity on cancerous, but no, not cancerous mitochondria, which was similar to what was seen by the whole extract (Figure 2; C, D). On the other hand, the mitochondria obtained from the extra tumoral tissue, the crude extract and all fractions of $T$. coronatus only at the highest dose $(1,000,1,500$ and $2,000 \mu \mathrm{g} / \mathrm{ml})$ induced a significant reduction in $\mathrm{SDH}$ activity (Figure 2; A, C, E, G, I)). Finally, the $\mathrm{IC}_{50}$ measured for crude extract and $\mathrm{F} 1$ fraction was $750 \mu \mathrm{g} / \mathrm{ml}$ and $550 \mu \mathrm{g} / \mathrm{ml}$, respectively. Based on the calculated $\mathrm{IC}_{50}$ the concentrations of 375, 750 and 1,500

Asian Pacific Journal of Cancer Prevention, Vol 193481 


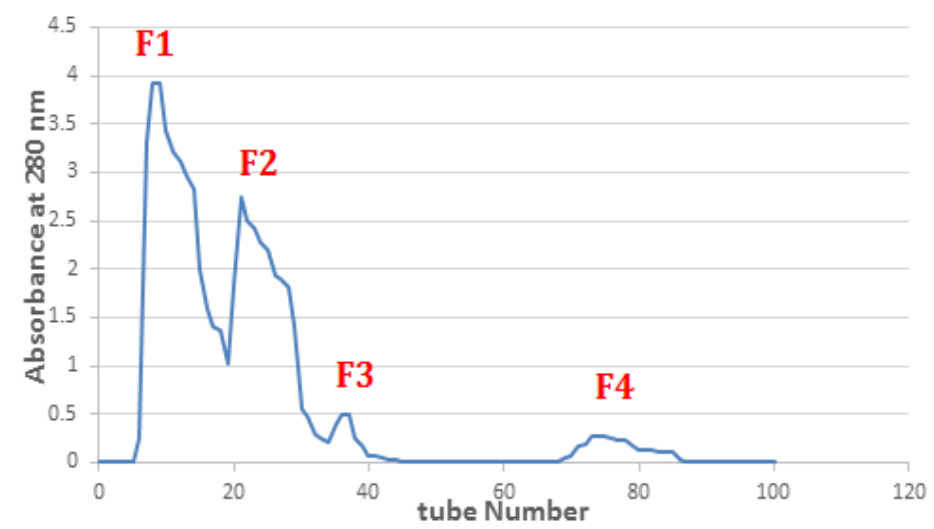

Figure 1. Gel Filtration Chromatogram of T. coronatus Crude Extract on Asephadex G-50 Column $(2.5 \times 150 \mathrm{~cm})$. All Fractionation Steps were Performed at $4{ }^{\circ} \mathrm{C}$.
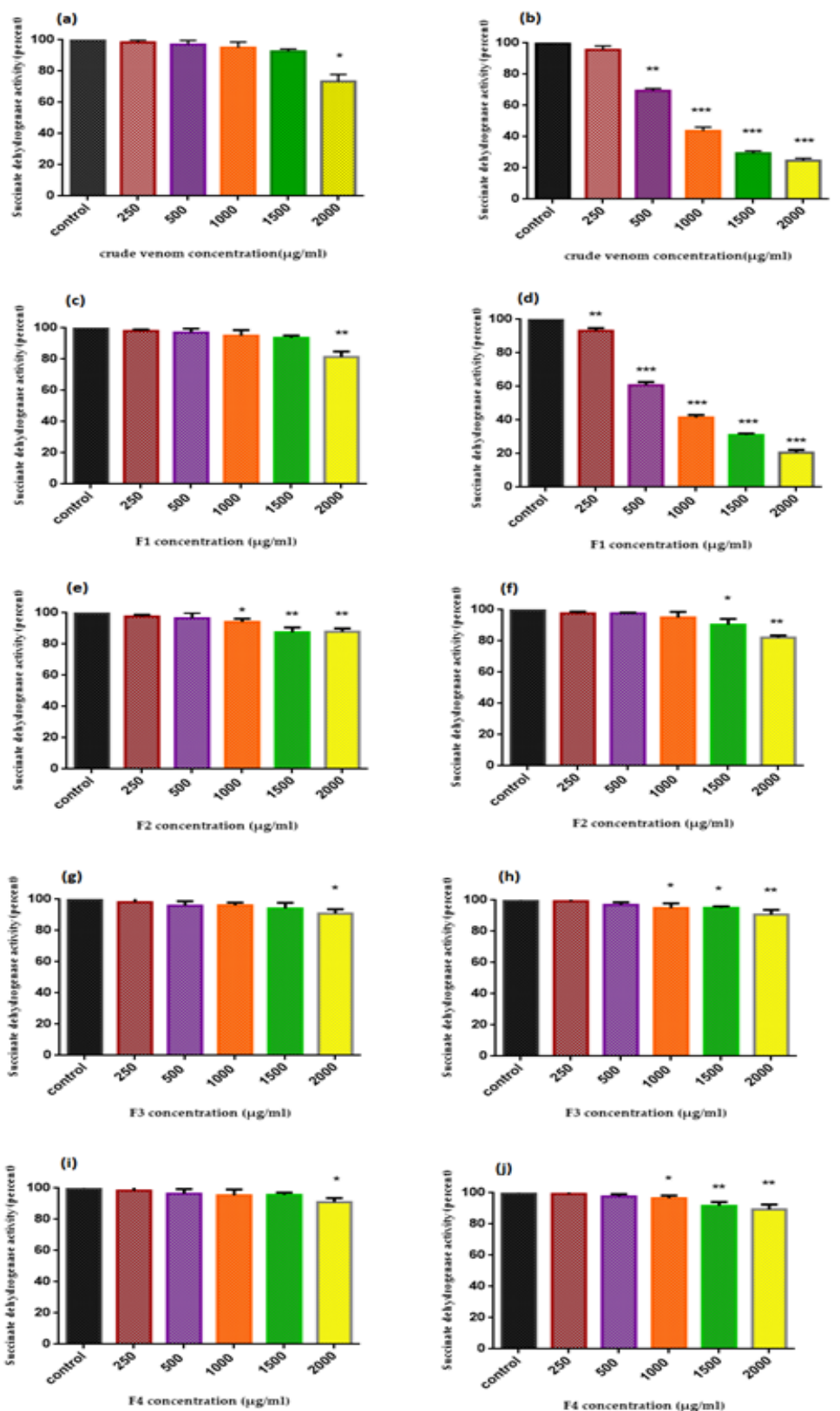

Figure 2. SDH Activity Assay. The effect of T. coronatus crude extract and its fractions (F1-F4) on mitochondrial succinate dehydrogenase activity measured by MTT assay. A (non-cancerous plus crude extract); B (EOC plus crude extract); C (non-cancerous plus F1 fraction); D (EOC plusF1 fraction); E (non-cancerous plusF2 fraction); F (EOC plusF2 fraction); G (non-cancerous plusF3 fraction); H (EOC plusF3 fraction); I (non-cancerous plus F4 fraction); $\mathrm{J}$ (EOC plusF4 fraction). Data are shown as mean $\pm \mathrm{SD}(\mathrm{n}=5) . *, * *, * * *$ and $* * * *$ show a significant difference in comparison with the corresponding control $(\mathrm{P}<0.05, \mathrm{P}<0.01, \mathrm{P}<0.001$ and $\mathrm{P}<0.0001$, respectively). 
(a)

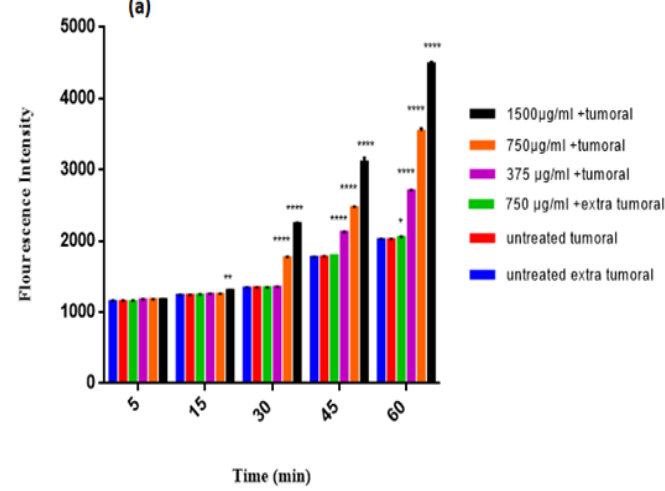

(b)

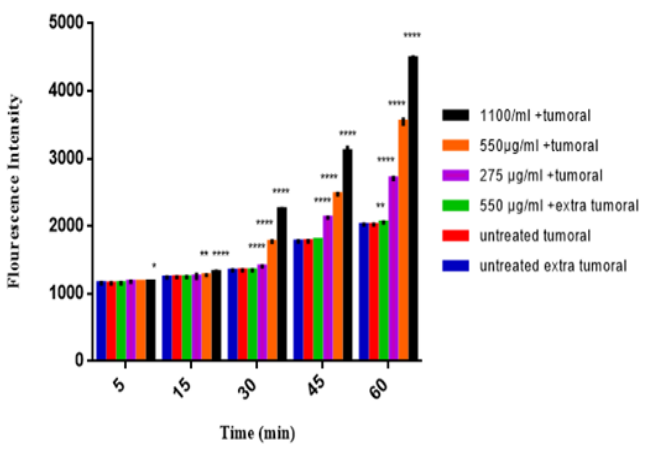

Figure 3. ROS Level Assay. The effect of various concentrations of crude extract $(375,750$ and $1500 \mu \mathrm{g} / \mathrm{ml})$ and F1 fraction $(275,550$ and $1100 \mu \mathrm{g} / \mathrm{ml})$ of $T$. coronatus extract on mitochondrial ROS level obtained from the extra tumoral and melanoma tissues. A (Crude extract); B (F1 fraction). Data are shown as mean \pm SD (n=5). *, ** and $* * * *$ show a significant difference in comparison with the untreated extra tumoral mitochondria $(\mathrm{P}<0.05, \mathrm{P}<0.01$ and $\mathrm{P}<0.0001$, respectively).

$\mu \mathrm{g} / \mathrm{ml}$ for crude extract and concentrations of 275,550 and $1,100 \mu \mathrm{g} / \mathrm{ml}$ for F1 fraction were selected to determine other mitochondrial toxicity parameters.

\section{Effect of crude extract and fraction 1 (F1) of T. coronatus on ROS formation}

As shown in Figure 3 (A-B), Our results indicated that the ROS generation in the mitochondria isolated from the extra tumoral tissue after 1 hour of incubation with different concentrations of crude extract $(375,750$ and $1500 \mu \mathrm{g} /$ $\mathrm{mL})$ and $\mathrm{F} 1$ fraction $(275,550$ and $1,100 \mu \mathrm{g} / \mathrm{mL})$ was significantly $(\mathrm{P}<0.05)$ raised, but not on the extra tumoral group, except for the extra tumoral groups treated with $1500 \mu \mathrm{g} / \mathrm{mL}$ of crude extract and $1100 \mu \mathrm{g} / \mathrm{mL}$ of F1 In the 60 minutes.

Effect of crude and fraction 1 (F1) of T. coronatus on mitochondria membrane potential (MMP)

Results in Figure 4(A-B) showed that, there was a significant collapse $(\mathrm{P}<0.05)$ in the MMP demonstrated by the re-distribution of the cationic fluorescent probe, Rhodamine 123 from the mitochondrial matrix into the suspension buffer after exposure to different concentrations of crude extract (Figure 4A) and F1 fraction
(Figure 4B) only in the mitochondria isolated from the extra tumoral tissues. Re-distribution of Rhodamine 123 from the mitochondria into the suspension buffer ends the quenching effect and increases the fluorescence intensity recorded by the fluorescence spectrophotometer. However, MMP levels did not significantly decline in extra tumoral mitochondria, except one time by high dose of crude extract and F1 fraction.

Effect of crude and fraction 1 (F1) of T. coronatus on mitochondrial swelling

Addition of crude extract $(375,750$ and $1,500 \mu \mathrm{g} / \mathrm{ml})$ (Figure 5A) and F1 fraction $(275,550$ and 1,100 $\mu \mathrm{g} / \mathrm{ml})$ (Figure 5B) to mitochondria obtained from the melanoma tissues led to the significant $(\mathrm{P}<0.05)$ mitochondrial swelling within 60 minutes of incubation. On the other hand, the addition of the same concentrations of crude extract and F1 fraction to the mitochondria obtained from the extra tumoral mitochondria did not induce any mitochondrial swelling.

Effect of crude extract and fraction 1 (F1) of T. coronatus on cytochrome c release

As shown in Figure $7(\mathrm{~A}-\mathrm{B})$, crude extract $(750 \mu \mathrm{g} / \mathrm{ml})$
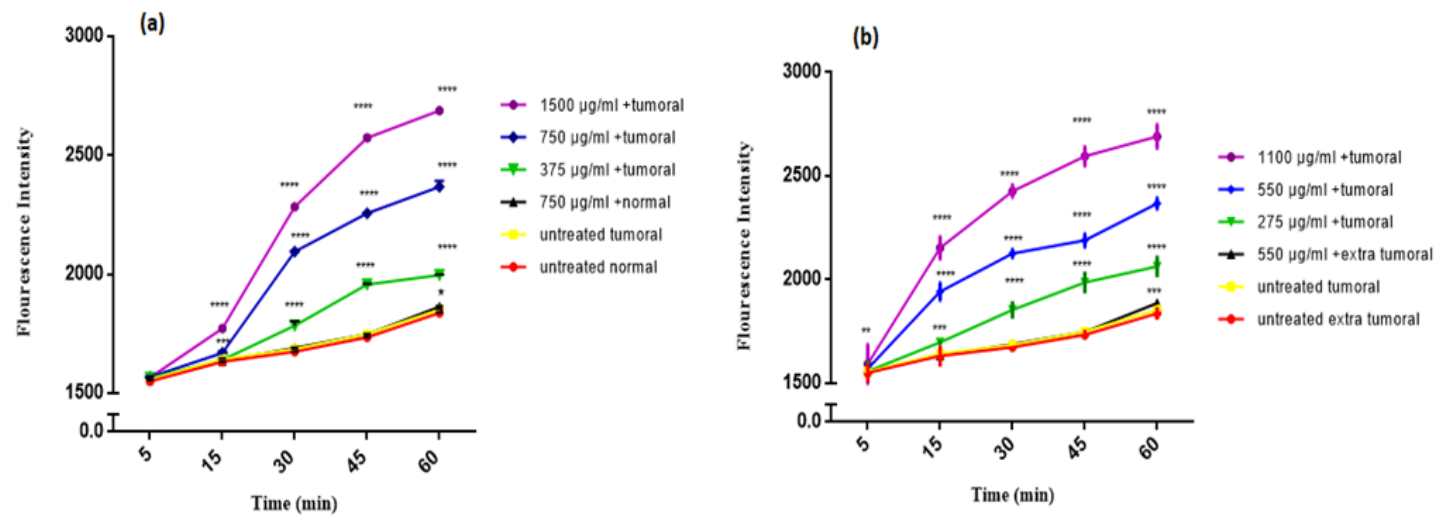

Figure 4. Mitochondria Membrane Potential (MMP) Assay. The effect of various concentrations of crude extract $(375,750$ And $1500 \mu \mathrm{g} / \mathrm{ml})$ and F1 fraction $(275,550$ And $1100 \mu \mathrm{g} / \mathrm{ml})$ of T. coronatus on the decline of the MMP on the mitochondria isolated from the extra tumoral and melanoma tissues. A (Crude extract); B (F1 fraction). Data are shown as mean $\pm \mathrm{SD}(\mathrm{n}=5) . *, * *$ And $* * * *$ shows a significant difference in comparison with the untreated extra tumoral mitochondria $(\mathrm{P}<0.05, \mathrm{P}<0.01$ and $\mathrm{P}<0.0001)$, respectively. 
(a)

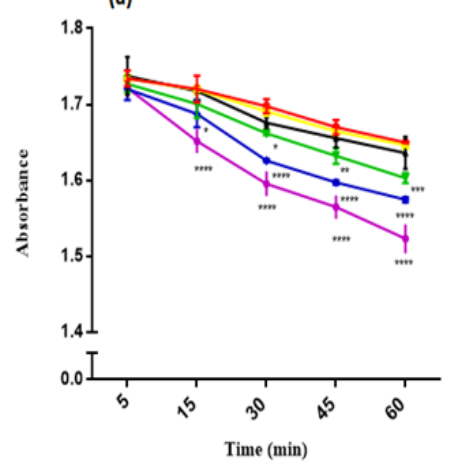

(b)

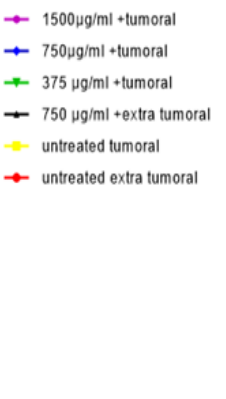

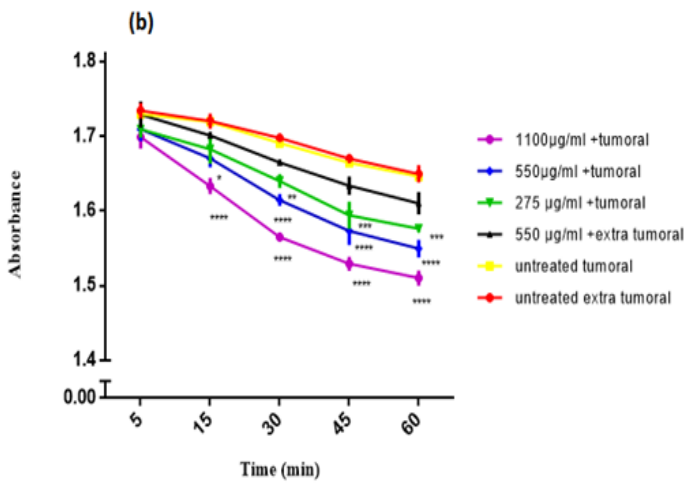

Figure 5. Mitochondrial Swelling Assay. The effect of various concentrations of crude extract (375,750 and 1500 $\mu \mathrm{g} / \mathrm{ml})$ and $\mathrm{F} 1$ fraction $(275,550$ and $1100 \mu \mathrm{g} / \mathrm{ml})$ of T. coronatus extract on the mitochondrial swelling in the extra tumoral and melanoma tissues. A (Crude extract); B (F1 fraction). Data are shown as mean $\pm \mathrm{SD}(\mathrm{n}=5)$. *, **, *** and $* * * *$ shows a significant difference in comparison with the untreated extra tumoral mitochondria $(\mathrm{P}<0.05, \mathrm{P}<0.01$, $\mathrm{P}<0.001$ and $\mathrm{P}<0.0001$, respectively).

and $\mathrm{F} 1$ fraction $(550 \mu \mathrm{g} / \mathrm{ml})$ induced a significant $(\mathrm{P}<0.05)$ release of cytochrome c only in the mitochondria obtained from the melanoma tissue. Alternatively, pretreatment of crude extract and F1 fraction treated melanoma mitochondria by MPT inhibitors and antioxidants, such as cyclosporine A (Cs.A) and butylated hydroxyl toluene (BHT) significantly inhibited cytochrome c release compared to melanoma mitochondria treated with crude extract and F1 fraction alone.

Effects offraction 1 (F1) of T. coronatus on cell cytotoxicity

As shown in Figure 6 (A and B), the inhibiting effect of different concentrations of fraction $\mathrm{F} 1$ of T.coronatus $(0$, $250,500,1,000,1,500$ and $2,000 \mu \mathrm{g} / \mathrm{ml}$ ) on cell viability was determined after 12 hours exposure with the MTT assay using isolated melanoma cells $\left(1 \times 10^{6}\right.$ cells $\left./ \mathrm{ml}\right)$ from both melanoma and extra tumoral tissues. However, F1 fraction of the extract significantly $(\mathrm{p}<0.05)$ reduced cell viability only in melanoma but not extra tumoral cells. $\mathrm{IC}_{50}$ of $\mathrm{F} 1$ fraction for 12 hours exposure on melanoma

(a)

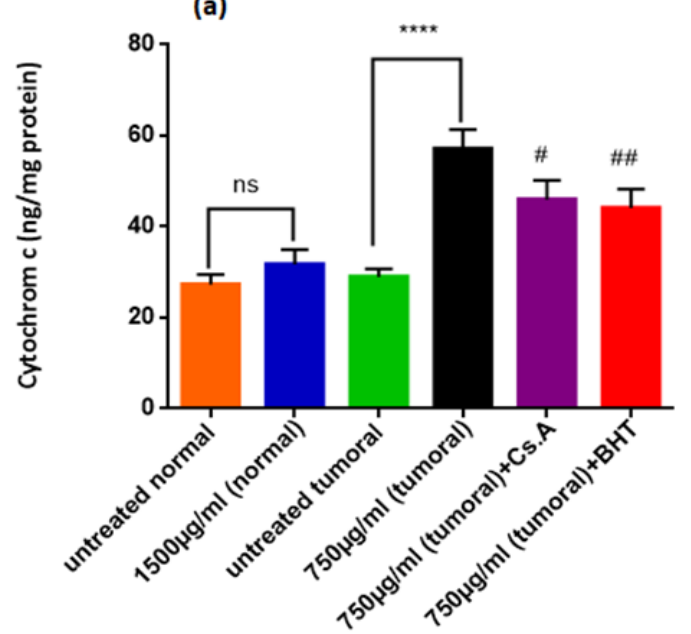

cells was $500 \mu \mathrm{g} / \mathrm{ml}$.

Effect of fraction 1 (F1) of $T$. coronatus extract on Caspase-3 activity

Our results showed that $\mathrm{F} 1$ fraction at a concentration of $500 \mu \mathrm{g} / \mathrm{ml}$ induced a significant $(\mathrm{P}<0.05)$ increase in activity of caspase- 3 only in the mitochondria obtained from the melanoma cells, but not extra tumoral mitochondria (Figure 8). On the other hand, our results showed that caspase-3 activation developed by fraction F1 $(500 \mu \mathrm{g} / \mathrm{ml})$ significantly reduced with pre-treatment of Ac-DEVD-CHO as a caspase- 3 inhibitor in cancerous melanoma cells.

Effect of fraction 1 (F1) of T. coronatus extract on cell apoptosis

The apoptosis was further quantified by the externalization of PS, assessed by annexin V-PI double staining at 12 hours following the exposure with F1 fraction of $T$. coronatus $(500 \mu \mathrm{g} / \mathrm{ml})$. The percentage of cell apoptosis in cancerous tissue caused by F1 fraction

(b)

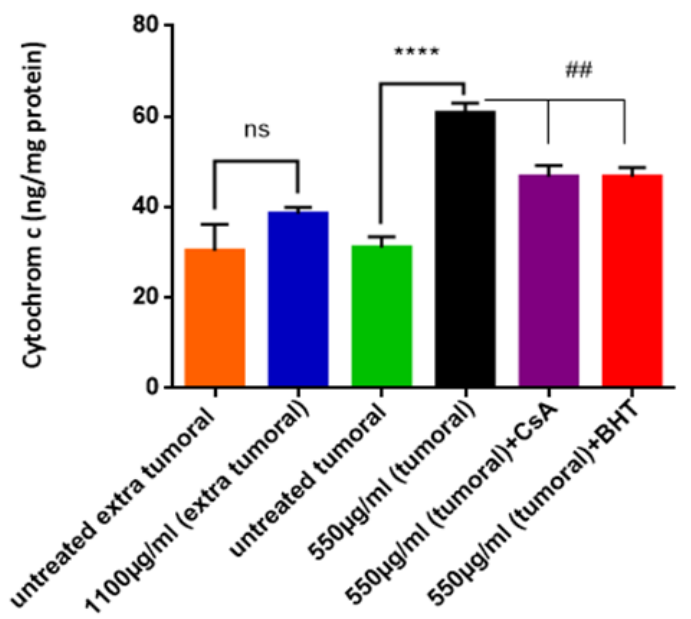

Figure 6. Cytochrome C Release Assay. The Effect of IC50 Concentration of Crude $(750 \mu \mathrm{g} / \mathrm{mL})$ and F1 Fraction $(550 \mu \mathrm{g} / \mathrm{ml})$ of T. coronatus on the Cytochrome C Release. A(crude extract); B(F1 fraction). Data are shown as mean $\pm \mathrm{SD}(\mathrm{n}=5)$. $* * * *$ shows a significant difference in comparison with the untreated tumoral $(\mathrm{P}<0.0001)$. \# and \#\# show significant difference in comparison with crude extract $(750 \mu \mathrm{g} / \mathrm{ml})$ and $\mathrm{F} 1(550 \mu \mathrm{g} / \mathrm{ml})$ of T. coronatus extract-treated tumoral mitochondria $(\mathrm{P}<0.05$ and $\mathrm{P}<0.001)$. 
(a)

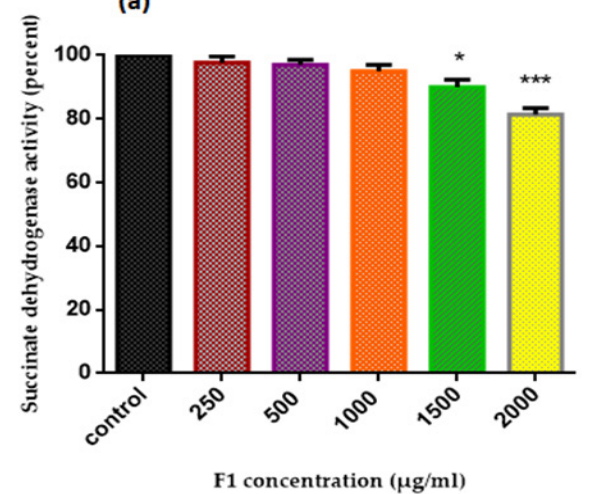

(b)

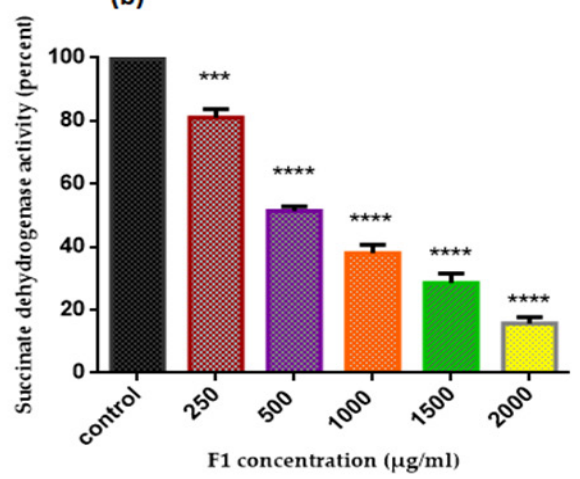

Figure 7. Effect of F1 Fraction of T. coronatus Extract Concentration $(0-2000 \mu \mathrm{g} / \mathrm{ml})$ on Cell Viability in Both Extra Tumoral (A) and Tumoral (B) Cells. Cells were treated with F1 fraction of T. coronatus and cell viability was measured by MTT Assay Following $12 \mathrm{~h}$ of exposure. Values are presented as mean $\pm \mathrm{SD}(\mathrm{n}=5)$. *, **, *** and **** shows a significant difference in comparison with the untreated tumoral and extra tumoral cells $(\mathrm{P}<0.05, \mathrm{P}<0.01$, $\mathrm{P}<0.001$ and $\mathrm{P}<0.0001$, respectively).

was significantly $(\mathrm{P}<0.05)$ increased, according to the result shown in Figure 9.

\section{Discussion}

Malignant melanoma of the skin is one the most aggressive type of skin cancer that incidence and mortality rate rising in worldwide particular in light-skin populations (Vaid et al., 2016; Ye et al., 2016). That remains a great challenge due to its significant resistance to conventional chemotherapy, which is mostly caused by an intrinsic resistance of neoplastic melanocytes to apoptosis (Barbi de Moura et al., 2012; Kalal et al., 2017). Therefore correcting the dysfunctional apoptotic program in melanoma cells may be a key requisite to overcome drug resistance and improve clinical outcome (Wong, 2011). The aim of this study is to investigate the selective toxicity and apoptotic effect of crude extract and fractions of the T. coronatus extract on cells and mitochondria isolated from the syngeneic animal model of melanoma tissue. Natural sources or synthetic analogues of these products remain a rich source of promising chemotherapeutic or chemo-preventive agents (Cragg and Pezzuto, 2016). Over the past decades, several new experimental anticancer agents derived from marine sources have entered preclinical and clinical trials. At present, the various bioactive compounds from different invertebrates (cone snails, soft coral, mollusk, sponges and other marine organisms) have been recognized as important sources of antitumor agents (Ruiz-Torres et al., 2017). In addition, reports indicate that approximately $75 \%$ of the 20,000 marine natural products are derived from marine invertebrates (Hu et al., 2011; Chen et al., 2015; Ruiz-Torres et al., 2017). Studies have reported that invertebrates are able to induce apoptosis signaling via decreasing Bcl-2 protein expression and also increasing

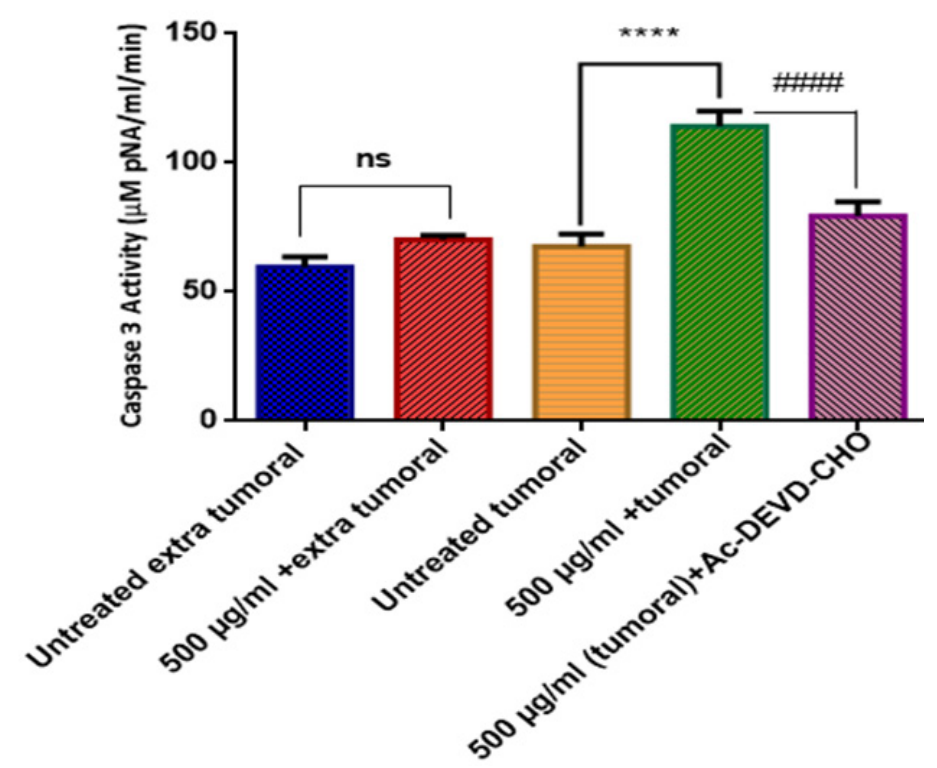

Figure 8. Effect of F1 fraction of T. coronatus $(500 \mu \mathrm{g} / \mathrm{ml})$ on the activity of caspase- 3 in melanoma and extra tumoral cells. Values are presented as mean $\pm \operatorname{SD}(n=5)$. *** show significant difference in comparison with the untreated melanoma cells $(\mathrm{P}<0.0001)$. \#\#\#\#show significant differences in comparison with $\mathrm{F} 1$ fraction $(500 \mu \mathrm{g} / \mathrm{ml})$ treated melanoma cells $(\mathrm{P}<0.0001)$. 
(a)

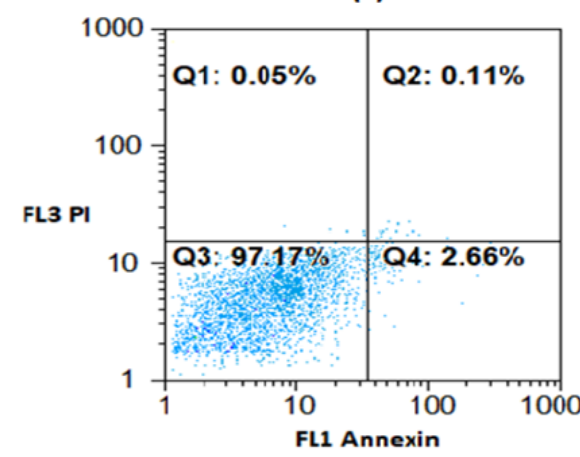

(c)

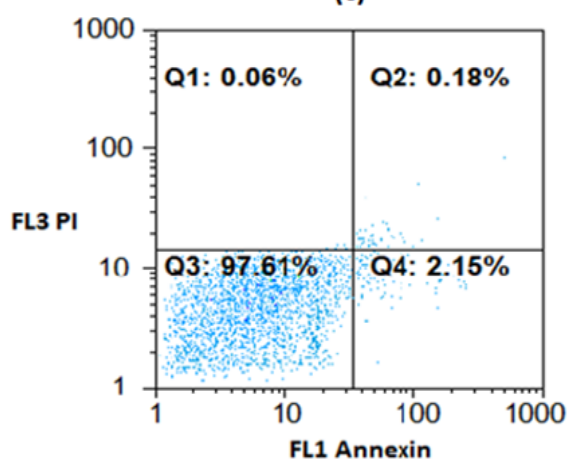

(b)

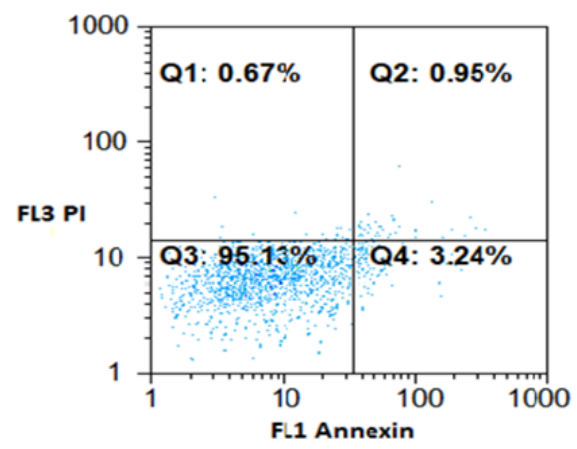

(d)

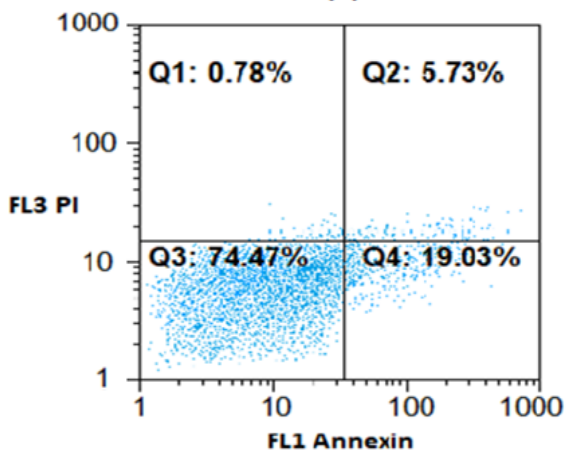

(e)

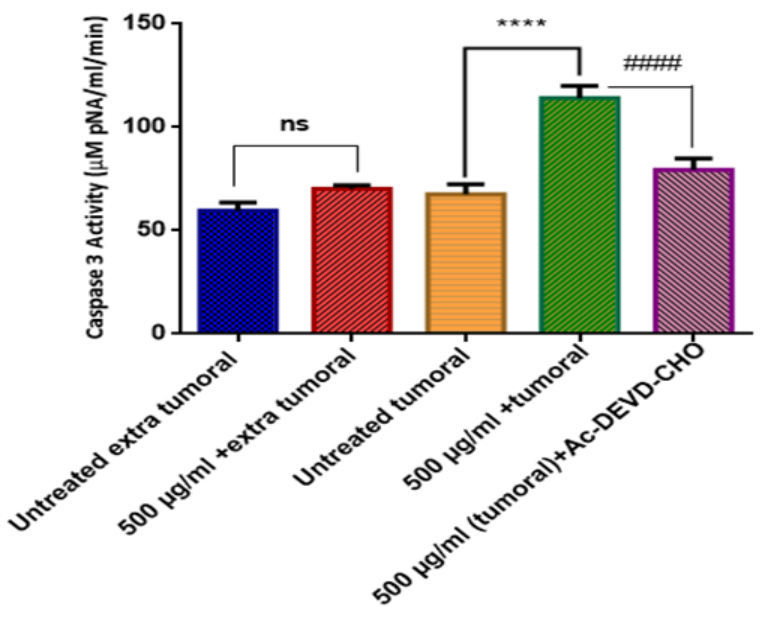

Figure 9. Analysis for Annexin-V and PI Staining of Extra Tumoral and Melanoma Cells Incubated with F1 Extract $(500 \mu \mathrm{g} / \mathrm{ml})$ for $12 \mathrm{~h}$. Only Annexin V, positive (+) and PI, negative $(-)$ cells were defined as apoptotic. A (untreated extra tumoral cells, Annexin V+/PI- $=2.66 \%$ ), B (extra tumoral cells after $12 \mathrm{~h}$ exposure of F1 fraction, Annexin V+/ $\mathrm{PI}-=3.24 \%$ ), C (untreated melanoma cells, Annexin V+/PI- $=2.15 \%$ ), D (melanoma cells after $12 \mathrm{~h}$ exposure of F1 fraction, Annexin V+/PI- = 19.03\%). Q1: \% necrotic cells, Q2: \% late apoptotic cells, Q3: \%Live cells, Q4: \%early apoptotic cells. The summarized apoptotic data (early \&later) was demonstrated at graph (E). Results are expressed as means $\pm \mathrm{SD}(\mathrm{n}=5),{ }^{*} * * * \mathrm{p}<0.0001$ vs. untreated extra tumoral cells.

Bax expression levels. Therefore, it is expected that in the future, bio prospecting efforts will continue to target marine invertebrates (Ruiz-Torres et al., 2017). According to our results, crude extract and its main fraction (F1) of the Persian Gulf sea snail, T. coronatus, induced apoptotic cell death in a concentration-dependent manner without cytotoxicity against extra tumoral cells. According to previous researches the most ROS in cells generated by the mitochondrial respiratory chain, that under hypoxic conditions with increasing ROS production lead to oxidative stress that it is serious in cellular signaling pathways in cancer (Wong, 2011). Several studies have suggested that high levels of ROS can stimulate an apoptotic program by activating pro-apoptotic factors such as Bax (Ghobrial et al., 2005; Wong, 2011). Our results showed that $T$. coronatus crude extract and its F1 fraction increased ROS levels in mitochondria isolated from cancerous cells but not extra tumoral cells. Oxidative 
stress induced through ROS is assumed to play a vital role in the melanoma carcinogenesis (Ayed et al., 2011; Morabito et al., 2012). In one study on leukemia cells, it was found, the ethyl acetate fraction of Meretrixlusoria extract, a marine mollusk increases ROS level (Pan et al., 2006). Accordingly, in this study, our findings showed that $T$. coronatus crude extract and its fraction 1 (F1) significantly $(\mathrm{P}<0.05)$ increased ROS production in a time and concentration related manner only in mitochondria isolated from melanoma cells but not extra tumoral healthy cells compared to their corresponding untreated mitochondria.

Following to ROS production, mitochondrial membrane potential (MMP) is disrupted via formation of permeability transition pores that leads to induction of mitochondrial permeability transition (MPT) (Wong, 2011; Theodosakis et al., 2014). The later causes mitochondrial swelling and release of several pro-apoptotic proteins such as cytochrome c, Smac/DIABLO and the apoptosis-inducing factor (AIF) from mitochondria into cytosol (Scatena, 2012; Theodosakis et al., 2014). Although both $T$. coronatus crude extract and its F1 fraction induced the MMP collapse in the mitochondria from the melanoma tissues, but F1 fraction collapsed MMP in lower concentrations in comparison to the crude extract. Increased mitochondrial swelling as an indicator of MPT was also monitored during our study. T. coronatus crude extract and its F1 fraction caused significant mitochondrial swelling again, only in the mitochondria obtained from cancerous but, not extra tumoral tissue along with cytochrome $\mathrm{c}$ release into cytosol which is also a consequence of MPT pore-opening. MPT is as associated with apoptotic protease activating factor 1 (APAF-1) and formation of a complex with pro-caspase-9, followed by activation of downstream caspases (Scatena, 2012). Moreover, pretreatment with both Cs.A as an inhibitor of MPT pore and BHT as a ROS scavenger completely blocked the release of cytochrome $\mathrm{c}$ from the mitochondria obtained from cancerous tissues, which proves our assumption that apoptosis induction by $T$. coronatus extract crude extract and its F1 fraction are due to the oxidative stress and relies on the opening of the MPT pore.

The caspase- 3 plays a terminative role of the apoptosis signaling as an important executioner. When activated, it cleaves a series of substrates, orchestrating apoptosis (Wong, 2011; Mirshamsi et al., 2017). In this study, our results showed that $\mathrm{F} 1$ fraction induced a significant increase of caspase- 3 activity in the animal melanoma cells and caused apoptosis enhancement. Therefore, we concluded that fraction 1 (F1) of $T$. coronatus could directly and selectively target mitochondria and induce apoptosis in melanoma cells and inhibits tumor growth. F1 fraction can therefore be a potential candidate as a novel anti-tumor agent against melanoma cells.

\section{Statement conflict of Interest}

No potential conflict of interest was reported by the authors.

\section{Acknowledgments}

The results presented in this article were partly extracted from the thesis of Dr. Fatemeh Zangeneh (Ph.D. graduate of Faculty of Pharmacy, Shahid Beheshti University of Medical Sciences) who performed her thesis under the supervision of Prof. Jalal Pourahmad and Prof. Mehrdad Faizi and Prof. Amir Vazirizadeh. The investigation was performed in Prof. Jalal Pourahmad's laboratory in the Faculty of Pharmacy, ShahidBeheshti University of Medical Sciences, Tehran, Iran.

\section{References}

Ayed Y, Boussabbeh M, Zakhama W, et al (2011). Induction of cytotoxicity of Pelagia noctiluca venom causes reactive oxygen species generation, lipid peroxydation induction and DNA damage in human colon cancer cells. Lipids Health Dis, 10, 232.

Barbi de Moura M, Vincent G, Fayewicz SL, et al (2012). Mitochondrial respiration--an important therapeutic target in melanoma. PLoS One, 7, e40690.

Bradford MM (1976). A rapid and sensitive method for the quantitation of microgram quantities of protein utilizing the principle of protein-dye binding. Anal Biochem, 72, 248-54.

Chen JW, Wu QH, Rowley DC, et al (2015). Anticancer agentbased marine natural products and related compounds. J Asian Nat Prod Res, 17, 199-216.

Cragg GM, Pezzuto JM (2016). Natural products as a vital source for the discovery of cancer chemotherapeutic and chemopreventive agents. Med Princ Pract, 25, 41-59.

Dana N, Javanmard SH, Rafiee L (2015). Antiangiogenic and antiproliferative effects of black pomegranate peel extract on melanoma cell line. Res Pharm Sci, 10, 117-24.

Eskandari MR, Fard JK, Hosseini MJ, et al (2012). Glutathione mediated reductive activation and mitochondrial dysfunction play key roles in lithium induced oxidative stress and cytotoxicity in liver. Biometals, 25, 863-73.

Fakhri A, Omranipour R, Fakhri S, et al (2017). Naja Naja Oxiana Venom fraction selectively induces ROS-mediated apoptosis in human colorectal tumor cells by directly targeting Mitochondria. Asian Pac J Cancer Prev, 18, 2201-8.

Ghobrial IM, Witzig TE, Adjei AA (2005). Targeting apoptosis pathways in cancer therapy. CA Cancer J Clin, 55, 178-94.

Grossman D, Altieri DC (2001). Drug resistance in melanoma: mechanisms, apoptosis, and new potential therapeutic targets. Cancer Metastasis Rev, 20, 3-11.

Hoel DG, Berwick M, de Gruijl FR, et al (2016). The risks and benefits of sun exposure 2016. Dermatoendocrinol, 8 , e1248325.

Hu G-P, Yuan J, Sun L, et al (2011). Statistical research on marine natural products based on data obtained between 1985 and 2008. Mar Drugs, 9, 514-25.

Kalal BS, Upadhya D, Pai VR (2017). Chemotherapy resistance mechanisms in advanced skin cancer. Oncol Rev, 11, 326.

Kigoshi H, Kanematsu K, Yokota K, et al (2000). Turbotoxins A and $\mathrm{B}$, novel diiodotyramine derivatives from the Japanese gastropod turbo marmorata. Tetrahedron, 56, 9063-70.

Lampl T, Crum JA, Davis TA, et al (2015). Isolation and functional analysis of mitochondria from cultured cells and mouse tissue. $J$ Vis Exp, 10, 52076.

Looi CY, Moharram B, Paydar M, et al (2013). Induction of apoptosis in melanoma $\mathrm{A} 375$ cells by a chloroform fraction of Centratherum anthelminticum (L.) seeds involves NF-kappaB, p53 and Bcl-2-controlled mitochondrial 
signaling pathways. BMC Complement Altern Med, 13, 166.

Malve H (2016). Exploring the ocean for new drug developments: Marine pharmacology. J Pharm Bioallied Sci, 8, 83-91.

Mirshamsi MR, Omranipour R, Vazirizadeh A, et al (2017). Persian Gulf Jellyfish (Cassiopea andromeda) Venom fractions induce selective injury and cytochrome $\mathrm{C}$ release in mitochondria obtained from breast adenocarcinoma patients. Asian Pac J Cancer Prev, 18, 277-86.

Morabito R, Condello S, Curro M, et al (2012). Oxidative stress induced by crude venom from the jellyfish Pelagia noctiluca in neuronal-like differentiated SH-SY5Y cells. Toxicol In Vitro, 26, 694-9.

Naserzadeh P, Jokar F, Vafaei F, et al (2017). Toxicity of new synthetic amphetamine drug mephedrone On Rat Heart mitochondria: a warning for its abuse. Xenobiotica, 7, 1-7.

Overwijk WW, Restifo NP (2001). B16 as a mouse model for human melanoma. Curr Protoc Immunol, 20, 20.1.

Pan MH, Huang YT, Ho CT, et al (2006). Induction of apoptosis by Meretrix lusoria through reactive oxygen species production, glutathione depletion, and caspase activation in human leukemia cells. Life Sci, 79, 1140-52.

Pettit GR, Tang Y, Knight JC (2005). Antineoplastic agents 545. isolation and structure of turbostatins 1-4 from the Asian Marine Mollusc Turbo stenogyrus(,1). J Nat Prod, 68, 974-8.

Qiu LN, Zhou YL, Wang ZN, et al (2012). ZGDHu-1 promotes apoptosis of chronic lymphocytic leukemia cells. Int $J$ Oncol, 41, 533-40.

Ruiz-Torres V, Encinar JA, Herranz-Lopez M, et al (2017). An updated review on marine anticancer compounds: The use of virtual screening for the discovery of small-molecule cancer drugs. Molecules, 22.

Salimi A, Roudkenar MH, Sadeghi L, et al (2015). Ellagic acid, a polyphenolic compound, selectively induces ROS-mediated apoptosis in cancerous B-lymphocytes of CLL patients by directly targeting mitochondria. Redox Biol, 6, 461-71.

Samel M, Tõnismägi K, Rönnholm G, et al (2008). 1-Amino acid oxidase from Naja naja oxiana venom. Comp Biochem Physiol B Biochem Mol Biol, 149, 572-80.

Scatena R (2012). Mitochondria and cancer: a growing role in apoptosis, cancer cell metabolism and dedifferentiation. $A d v$ Exp Med Biol, 942, 287-308.

Seydi E, Hosseini SA, Salimi A, et al (2016a). Propolis induce cytotoxicity on cancerous hepatocytes isolated from rat model of hepatocellular carcinoma: Involvement of ROS-mediated mitochondrial targeting. PharmaNutrition, 4, 143-50.

Seydi E, Rasekh HR, Salimi A, et al (2016b). Myricetin selectively induces apoptosis on cancerous hepatocytes by directly targeting their mitochondria. Basic Clin Pharmacol Toxicol, 119, 249-58.

Siegel RL, Miller KD, Jemal A (2018). Cancer statistics, 2018. CA Cancer J Clin, 68, 7-30.

Talari M, Seydi E, Salimi A, et al (2014). Dracocephalum: novel anticancer plant acting on liver cancer cell mitochondria. Bio Med Res Int, Article ID 892170.

Theodosakis N, Micevic G, Kelly DP, et al (2014). Mitochondrial function in melanoma. Arch Biochem Biophys, 563, 56-9.

Tian F, Lu JJ, Wang L, et al (2012). Expression of c-FLIP in malignant melanoma, and its relationship with the clinicopathological features of the disease. Clin Exp Dermatol, 37, 259-65.

Vaid M, Singh T, Prasad R, et al (2016). Bioactive proanthocyanidins inhibit growth and induce apoptosis in human melanoma cells by decreasing the accumulation of beta-catenin. Int J Oncol, 48, 624-34.

Vazirizadeh A, Mohebbi G, nabipour I (2017). The effect of crude extract of turbo coronatus from the Persian Gulf on serum biochemical parameters and hematiological parameters of rats. Iran South Med, 20, 207-16.

Wong RS (2011). Apoptosis in cancer: from pathogenesis to treatment. J Exp Clin Cancer Res, 30, 87.

Ye T, Zhu S, Zhu Y, et al (2016). Cryptotanshinone induces melanoma cancer cells apoptosis via ROS-mitochondrial apoptotic pathway and impairs cell migration and invasion. Biomed Pharmacother, 82, 319-26.

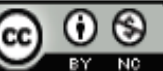

This work is licensed under a Creative Commons AttributionNon Commercial 4.0 International License. 